\title{
ASPECTS OF DIURETIC THERAPY CHRONIC HEART FAILURE BY EVIDENCE-BASED MEDICINE
}

\section{G.I. Hrebtiy}

Abstract. The study analysis of endothelial vascular function in patients with chronic heart failure under various schemes diuretic therapy: a non-receiving furosemide and continuous use Torsemide sustained release over 6 months of treatment. The data indicate that in selected groups of patients under the influence of non-permanent furosemide therapy endothelium vasodilation after 6 months increased by $63,1 \%$, while the daily intake Torsemide - by $97,9 \%(p=0,036)$.

Key words: chronic heart failure, diuretic therapy, endothelial function.

Bukovinian State Medical University (Chernivtsi)

Рецензент - проф. І.А. Плеш

Buk. Med. Herald. - 2015. - Vol. 19, № 1 (73). - P. 197-200

Надійшла до редакції 24.11.2014 року

(C) Г.І. Хребтій, 2015

УДК 613.6:001.5+002.1

\author{
В.Г. Цуркан
}

\section{ПСИХОЕМОЩЙНА НАПРУЖЕНІСТЬ ОПЕРАТОРІВ В УМОВАХ ГРУПОВОЇ ДІЯЛЬНОСТІ}

\author{
Донецький відокремлений підрозділ Державної установи \\ "Лабораторний центр на залізничному транспорті \\ Держсанепідслужби України”, м. Донецьк
}

\begin{abstract}
Резюме. Встановлені з теоретичних позицій особливості мобілізації резервів адаптації організму в диспетчерів, які керують рухом поїздів, а також взаємозв'язків психофізіологічних функцій при вирішенні
\end{abstract}

проблеми профілактики професійно зумовлених захворювань.

Ключові слова: оператор, напруженість, функціональний стан.
Вступ. Оператори-диспетчери залізничного транспорту (чергові по станції, поїзні диспетчери, чергові по горці тощо) складають чисельну професійну групу, яка безпосередньо впливає на безпеку руху, оскільки професійна надійність пов'язана 3 впливом на неї різних чинників, зокрема таких, як відповідність психофізіологічної організації суб'єкта вимогам професії, рівню професійної підготовки тощо $[3,10]$. При організації швидкісного руху на існуючих залізничних лініях передбачається продовження створення нових автоматизованих систем і інформаційних технологій $[4,17]$, що призводить до змін у системі управління поїзною роботою за рахунок розвитку нової моделі диспетчерського керування (Головний центр управління рухом і шести регіональних центрів). Це потребує, відповідно до загальних напрямів розвитку медицини, проведення визначення умов дотримання безпеки руху по людському фактору, 3 урахуванням того, що на етапі виконання виробничих обов'язків і в процесі міжзмінного відпочинку працездатність залізничних операторів може знижатися. Властивості людини-оператора виконувати відповідальні функції вивчені поки ще недостатньо. Насамперед це зумовлено складністю і неоднозначністю процесів, властивих інтелектуальним організмам, які, у свою чергу, вимагають створення складних моделей [9].
Мета дослідження. Визначити загальні особливості напруженості організму, за так званої психофізіологічної проблеми співвідношення нервових і психічних розладів, яка тісно пов'язана 3 проблемою загального стану здоров'я, при взаємодії людини і обладнання в процесі групової операторсько-управлінської діяльності на трасах залізничних перевезень.

Матеріал і методи. Потреба теоретичного синтезу науково-прикладних даних вирішена за рахунок використання при виконанні роботи експертно-аналітичних методів дослідження. Методологічною основою проведеної роботи були наукові праці і розробки вітчизняних учених, що присвячені подальшому розвитку теорії функціональних систем, засадам експериментальних та фізіологічних досліджень, оскільки професійна діяльність диспетчера на залізничному транспорті, як людини-оператора, характеризується керуванням значною кількістю об'єктів, які контролюються, високою відповідальністю при виборі оптимальних рішень у різних оперативних ситуаціях, можливим виникненням стресу при відмовах обладнання і аваріях $[1,7,8]$.

Результати дослідження та їх обговорення. Більшість стресових ситуацій на виробництві виникають саме через необхідність забезпечувати успішну діяльність за умов дефіциту часу, висо-

(C) В.Г. Цуркан, 2014 
Результати анкетного опитування диспетчерів СЦК (\% від загальної кількості диспетчерів, які відповіли)

\begin{tabular}{|c|c|c|}
\hline \multirow{2}{*}{ Види індивідуальних оцінок } & \multicolumn{2}{|c|}{ Групи опитаних } \\
\cline { 2 - 3 } & $\begin{array}{c}\text { На початку впровадження ЄЦК } \\
(\mathrm{n}=50)\end{array}$ & $\begin{array}{c}\text { Після впровадження профілактич- } \\
\text { них заходів в ЄЦК } \\
(\mathrm{n}=68)\end{array}$ \\
\hline Збільшення емоційного навантаження & 100 & 43,5 \\
\hline Збільшення втомленості & 100 & 42 \\
\hline Неможливість зосередитися & 92 & 17,4 \\
\hline Заважає скупчення людей & 96 & 23,2 \\
\hline
\end{tabular}

Таблиця 2

Прояви психоневрологічних станів у диспетчерів СЦК (n=68)

\begin{tabular}{|c|c|}
\hline Тип реакції & Питома вага, \% \\
\hline Почуття головного болю & 43,47 \\
\hline Порушення сну & 21,73 \\
\hline Агресивність & 15,94 \\
\hline Депресія & 7,24 \\
\hline Плаксивість & 4,34 \\
\hline
\end{tabular}

кої відповідальності за безаварійність роботи, за життя та здоров'я людей, а розробка допустимих рівнів емоційної напруженості, психоемоційного стресу на виробництві все ще залишається проблемою для медицини праці [7]. У диспетчерів станцій спостерігаються [16] характерні особливості розумової втомленості і психоемоційної напруженості під впливом їх праці. У 20-25 \% піддослідних фізіологічні функції змінювалися вже за 30-40 хвилин до роботи. Факт початку роботи, для цих осіб, служив сигналом формування напруженого емоційного стану. На протязі перших 4-5 годин роботи у значної частини диспетчерів станцій зростав артеріальний тиск. Позитивний результат для безпеки руху і перевізного процесу на залізничному транспорті, на початку створення єдиних дорожніх центрів керування (СЦК), забезпечив метод ситуаційного керування, який оснований на побудові узагальненої семантичної моделі структури і законів функціонування великих транспортних систем, для яких точна математична модель або відсутня, або іiї застосування через громіздкість практично недоцільно. Наявні дані щодо зміни функціонального та психоемоційного стану диспетчерів під впливом змін умов праці [16] показали, що при подальшому розвитку управлінського процесу і самої управлінської структури диспетчерського керування рухом поїздів, які стають ще більше залежними від інформаційних технологій (диктуються виробниками комп'ютерної техніки, програмного забезпечення i корпоративних інформаційних систем) $[4,9,17]$, необхідно виходити 3 того, що низька ймовірність досягнення мети веде до нега- тивних емоцій (страх, тривога, гнів, образа тощо), а збільшення ймовірності того, що потреба буде задоволена (порівняно з прогнозом, який мав місце раніше), породжує позитивні емоції задоволення, радості і торжества $[11,12]$. Постійна ж психоемоційна напруженість визначається самим характером і умовами праці операторів та лежить в основі розвитку психопатологічних змін в організмі, серед яких ведуче місце займають граничні психічні розлади, які вважають наслідком виражених зрушень із боку фізіологічних процесів [13], а різного роду групи завжди були об'єктом соціально-психологічного аналізу. Операторська діяльність, яка потребує особливої психоемоційної напруженості і відповідальності, формує такий стиль у роботі, при якому схильність до глибокого і довгого переживання негативних емоцій може мати провідне значення в розвитку та прогресуванні артеріальної гіпертензії, яка, у свою чергу, сприяє підвищенню напруження всіх професійно-значимих функцій, які потрібні для забезпечення необхідної якості праці, що може призводити до втомленості і погіршення розумової працездатності, зниження продуктивності професійної діяльності [5, 7]. Навіть при реалізованих профілактичних заходах з оптимізації умов праці на робочих місцях диспетчерів ЄЦК [16], при освоєнні диспетчерського керування, фахівцям доводиться створювати власну систему досвіду шляхом обмірковування і аналізу, шляхом практичного випробування та закріплення, шляхом прямого завчання. Ця нова форма організації праці диспетчерського керування дала можливість більш оперативно і якісно здійснюва- 
ти аналіз оперативної обстановки на трасах перевезень та в найкоротші строки приймати адекватне виважене колективне рішення 3 усунення перешкод та недоліків, що повсякчасно виникають у реальних умовах експлуатації залізничного транспорту. Необхідність дії на основі якостей особистостей, професійного і людського обліку, індивідуального стилю, а також відношення до спільної (групової) діяльності дозволяють сформувати психологічне теперішне, оскільки виконання трудових функцій неможливе без спілкування і впливу групи на індивіда [12], тим більше при зростанні напруженості праці диспетчерів за рахунок таких компонентів, як "евристична діяльність”, відповідальність за безпеку пасажирів та вантажів, зростання обсягу та високої щільності отримуваної та переробленої інформації. Виходячи із сумарної оцінки усіх вивчених чинників, праця диспетчерів СЦК $є$ дуже напруженою. Напрямок оцінки фізіологічних зрушень в організмі диспетчерів при впровадженні СЦК був визначений тим, що діяльність із керування рухом потягів безперервна і проходить за відсутності заданого алгоритму. Тобто підхід, при якому про розвиток втомленості свідчить зниження продуктивності та якості виконаної роботи, а працездатність оцінюють за кількістю розв'язаних завдань за визначений час (кількісний показник) і за числом помилок (якісний показник), не міг бути застосований. Виходили з того, що багато фізіологічних функцій підпадають під виражений психогенний вплив. В одних людей цей вплив більший, у інших - менший, а в нейрофізіології і нейропсихології загальновідома реальність центрального, у тому числі психічного (свідомого), контролю периферійної сенсорної інформації. За відсутності загальноприйнятого вичерпного тесту, за необхідності свідомого обмеження кількості елементів психофізіологічного дослідження [3] у процесі виробничого експерименту, застосовуються найбільш інформативні [6] показники психофізіологічних функцій - показники простої та складної зорово-моторної реакції. Проведені дослідження [8] показали те, що при збільшенні фізіологічної ціни роботи працездатність може деякий час залишатися на потрібному рівні. Можливо, що в даному випадку має місце вибіркова мобілізація фізіологічних функцій, оскільки пізніше отримані дані [16] підтвердили те, що і розумова працездатність диспетчерів ЄЦК упродовж змін підтримується на незмінному рівні, тому що емоційне напруження виникає в процесі оціночної, мотиваційної діяльності, зв'язаної з вибором альтернатив, скерованої зміни організації умов трудової діяльності у відповідності з домінуючою потребою $[7,8]$. Тобто, до поняття норми в працюючих можуть входити не тільки середні величини, які характеризують їх певну фізіологічну діяльність і закономірно змінюються в процесі трудової діяльності та супроводжуються зниженням певних функцій організму, а і можливості довгий час підтримувати їх на оптимальному рівні. Це пов'язано з можливістю комунікативного аспекту активності нервової системи (поряд 3 інтелектуальним і психомоторним аспектами), при якому стійкість спілкування, при груповій діяльності диспетчерів (стабільність соціальних контактів), більш тісно пов'язана зі змістовним аспектом активності, ніж з іiі динамічним аспектом $[11,12]$. Три аспекти активності є відносно незалежними один від іншого, але їх спільна дія забезпечує оптимальний рівень взаємодії індивіда 3 навколишнім середовищем. Безумовно, що професійна праця диспетчерів СЦК, у зв'язку з навантаженням на організм при інтенсивній роботі з отримання інформації, іiі аналізу, прийняттю рішення, реалізації прийнятого рішення, характеризується нервовою напруженістю. Отримані ж дані щодо зниження захворюваності диспетчерів СЦК, які свідчать про зменшення навантаження на їх організм з боку шкідливих виробничих чинників [16], за відсутності хронічних захворювань нервової системи, збігаються із сучасними уявленнями про те, що хвороба і непрацездатність - поняття неідентичні, оскільки існують випадки захворювань,за яких функціональні порушення не різко виражені [15]. В умовах СЦК диспетчери активно обмінюються інформацією, діють колегіально, шукають і знаходять психологічну підтримку в групі саме для того, щоб послабити негативні почуття, а сам факт генерування емоцій у ситуації прагматичної невизначеності транспортного процесу пояснюється їх адаптивним компенсаторним значенням. Але компенсаторна функція емоцій не вичерпується підвищеною мобілізацією вегетативної нервової системи. Виникнення емоційного напруження супроводжується переходом до інакших, ніж у спокійному стані, форм поведінки, принципів оцінки зовнішніх сигналів і реагування на них. Як відомо [5], участь у процесі прийняття рішень накладає на особистість відповідні моральні зобов'язання і підвищує рівень іiі мотивації, якщо їй ще належить виконати ці рішення. Важливою перевагою групових рішень $\epsilon$ те, що вони можуть сприйматися більш легітимними порівняно 3 рішеннями, які приймаються одноосібно. Можливо, саме ведуча або домінуюча мотивація, у взаємозв'язку з оцінкою навколишнього середовища і 3 урахуванням індивідуального досвіду диспетчерів, визначає послідовність формування цілеспрямованої поведінки і її сенсорного забезпечення. Мотиваційне збудження (домінуюча мотивація), яке подавляє інші мотивації і скеровує поведінку організму на досягнення результату та спонукає організм до цілеспрямованої поведінки, є стійким і довго зберігається, тобто доки не буде задоволена потреба, яка його викликала. При цьому внутрішня активність нервової системи проходить на тлі постійного зв'язку і корегування із зовнішнім середовищем [14]. Подібний постійний зв'язок із середовищем робить можливим постійний контроль оператора над своїми діями, за рахунок наявності внутрішньої програми дій, яка є узгодже- 
ною, головним чином, з вимогами виробничого середовища і соціальних умов. Більша частина поведінки диспетчерів складається 3 відбитих реакцій і автоматичних навичок, але за свободи вибору, творчому підході до вирішення виникаючих проблем, осмисленні віддалених наслідків ухвалених рішень.

Однак діяльність може погіршуватися і при зменшенні активації та зникненні емоційного забарвлення, що нерідко спостерігається в умовах монотонної обстановки. Поміркована ж ступінь емоційного напруження може підвищити ефективність діяльності і зменшити кількість помилок. Прикладом компенсаторної функції емоцій на популяційному рівні може служити імітаційна поведінка, яка характерна для емоційно збудженого мозку, тобто коли в суб'єкта немає даних або часу для самостійного і повною мірою обгрунтованого рішення, йому залишається покластися на приклад інших членів групи. Тим більше, що проблемними ситуаціями в процесі керування рухом поїздів $є$ вельми розповсюджені форми нових завдань, які потребують від оператора максимуму професійних знань, зусиль волі, творчого підходу і все це, нерідко, у досить стислі строки. Враховуючи відповідальність диспетчерів, за безаварійний рух поїздів, формою пошуку тут не може виступати "метод проб і помилок”, імовірне прогнозування, яке отримало в кібернетиці назву теорії динамічного програмування. Динамічність же розумової діяльності людини формується, перш за все, у процесі навчання і виховання, під впливом зовнішніх умов, які змінюються $[3,7,11,14]$. При груповій діяльності диспетчерів і спостерігається дійсна творчість, коли рішення знаходяться на основі більш глибокого узагальнення, тобто, при добре вираженій високопрофесійній направленості процесу керування рухом поїздів, коли має місце колективний відбір деяких найбільше імовірних можливостей.

Але навіть в дуже добре організованому керованому процесі управління рухом поїздів, не може бути усунутим момент випадковості, при здійсненні конкретної дії з усунення виникаючих проблем, як однієї з багатьох рівних можливостей (більш імовірних) для даної диспетчерської системи. На залізничному транспорті збій системи керування компенсується за рахунок втручання людини-оператора [9], при якому, за даними проведеного анкетування (табл. 1) у диспетчерів ЄЦК, вже після впровадження профілактичних заходів, має місце почуття підвищеної напруженості й емоційного навантаження під час роботи.

Анкетне опитування також підтвердило наявність короткочасних і легко виражених невротичних станів (табл. 2), пов'язаних із найбільш типовими психологічними проявами емоційної напруженості праці, тобто суб'єктивні відчуття обстежених диспетчерів, навіть при сприятливих умовах праці, можуть свідчити про наявність невротичної травматизації.
Слід зауважити, що до роботи в ЄЦК були допущені диспетчери, які вже пройшли професійний відбір перед роботою на станціях, при якому була врахована стійкість до дезорганізуючого впливу надмірного емоційного напруження, яка залежить від їх індивідуально-типологічних особливостей. Відповідно диспетчери, які вже мали стаж за своєю професією, напевно, можуть бути віднесені до "здорових трудоголіків" [2], що вболівають за свою справу і ії результати, оскільки робота відповідає рівню їх знань і умінь. Поряд 3 цим, для екстремальних ситуацій, які викликають стани стресу або напруженості, роль якостей нервової системи суттєво збільшується - ведуче значення припадає на уродженні якості нервової системи. Однак, якщо екстремальність умов не дуже велика, 3'являються можливості компенсації якостей, яких недостає, а отримані дані [16] про наявність формування певних специфічних психофізіологічних пристосувальних механізмів при груповій роботі в ЄЦК, дозволяють зняти питання щодо придатності осіб зі слабкою нервовою системою для колективної операторської діяльності, оскільки сама по собі динамічна система передбачає творче відношення, яке залежить і від професійного досвіду, рухомості, а разом $з$ тим, врівноваженості нервових процесів. Свідченням останнього є відсутність психоневрологічних захворювань та суттєве зменшення загальної захворюваності у диспетчерів СЦК, порівняно $з$ диспетчерами станцій. Так, загальна захворюваність у диспетчерів СЦК була нижча за кількістю випадків захворювань у 2,77 раза, за кількістю днів захворювання у 3,5 раза, а питома вага диспетчерів СЦК, які не хворіли, становить 78,7 \% (тобто більше 50 \%, а такий індекс здоров'я колективу вже розцінюється як задовільний). Виявлений позитивний вплив групової операторської діяльності на рівень психоемоційної напруженості пояснений підтримуючою функцією колективу диспетчерів, при об'єднанні в тяжких для них ситуаціях.

\section{Висновок}

Таким чином, особливістю групової операторської праці диспетчерів стає можливість спільної відповідальності за результати діяльності щодо забезпечення перевізного процесу, що, при реалізованих профілактичних заходах може дозволити знизити вплив психоемоційного навантаження при формуванні керування рухом поїздів за наступними рівнями управління [4].

Перспективи подальших досліджень. При визначенні соціально-психологічного мікроклімату в групах диспетчерів, які будуть задіяні в процесі реформування диспетчерського управління на залізничному транспорті, необхідне врахування ефекту позитивного сполучення індивідуальних якостей іiі членів, а також проведення детального аналізу взаємозв'язків між окремими параметрами регуляторних систем їх організму, в процесі реалізації нових автоматизованих систем i інформаційних технологій, впровадження яких 
передбачається при організації керування швидкісним рухом на залізничному транспорті, що також потребує пошуку ресурсів відновлення працездатності.

\section{Література}

1. Березанцев А.Ю. Психосоматические и соматоформные расстройства (аналитический обзор, часть 1) / А.Ю. Березанцев // Рос. психиатр. ж. - 2001. - № 3. C. 61-69.

2. Гибнер С.С. Феномен трудоголизма у мужчин / С.С. Гибнер // Мед. психол. - 2008. - Т. 3, № 1. C. 4-7.

3. Кальниш В. Психологически-социальные и экономические аспекты профессионального отбора / В. Кальниш, А. Ена // Охрана труда. - 2002. - № 11. C. $37-38$.

4. Кизим О.В. Оптимізація системи управління перевезеннями / О.В. Кизим, С.В. Кизим // Інноваційні технології на залізничному транспорті: Зб. наук. праць. Луганськ, 2013. - С. 234-237.

5. Клиническая психология / Под ред. Б.Д. Карвасарского. - СПб.: Питер, 2008. - С. 229-250.

6. Кравчук В.В. Особливості психофізіологічного стану військових льотчиків різного віку і стану здоров'я / В.В. Кравчук // Укр. ж. 3 пробл. мед. праці. - 2006. № 3. - C. 17-26.

7. Кундісв Ю.І. Напруженість праці як фактор професійного стресу та ризику здоров'ю / Ю.І. Кундієв, В.І. Чернюк, В.М. Шевцова // Укр. ж. $з$ пробл. мед. праці. - 2005. - № 3-4. - С. 90-98.

8. Ластовченко В.Б. Особенности влияния факторов трудового процесса на суточную динамику психофизиологических показателей операторов / В.Б. Ластов- ченко // Укр. ж. 3 пробл. мед. праці. - 2006. - № 3. C. $10-16$.

9. Мойсеєнко В.І. Вплив часу відновлення на професійну надійність залізничних операторів / В.I. Мойсеєнко // Залізничний транспорт України. - 2013. - № 3/4. C. 8-9.

10. Наявное состояние функциональной надежности резерва операторов-диспетчеров / В.Г. Брусенцов, О.В. Брусенцов, В.Н. Самсонкин, П.А. Воронько // Залізничний транспорт України. - 2009. - № 5. C. 23-25.

11. Психофизиология / Под ред. Ю.И. Александрова. СПб.: Питер, 2001. - 371 с.

12. Самоукина Н.В. Психология профессиональной деятельности. - СПб.: Питер, 2003. - 224 с.

13. Сергета I.В. Актуальні проблеми психогігієни / I.В. Сергета // Гігієнічна наука та практика на рубежі століть: Матеріали 14 з'їзду гігієністів України. - К., 2004. - T. 2. - C. 202-204.

14. Смирнов В.М. Физиология сенсорных систем и высшая нервная деятельность / В.М. Смирнов, С.М. Будылина. - М.: Академия, 2003. - 304 с.

15. Ткачишин В.С. Основні положення лікарськотрудової експертизи / В.С. Ткачишин // Пробл. мед. 2001. - № 5-6. - С. 19.

16. Цуркан В.Г. Психогігієнічний вплив умов праці диспетчерів при новій технології управління процесом перевезень / В.Г. Цуркан // Укр. ж. клін. та лаб. мед. 2009. - T. 4, № 2. - С. 187-193.

17. Чернецька-Білецька Н.Б. Аналіз проблем впровадження швидкісного руху на залізничному транспорті / Н.Б. Чернецька-Білецька, М.С. Костишак // Інноваційні технології на залізничному транспорті: Збірник наукових праць. - Луганськ, 2013. - С. 176-179.

\section{ПСИХОЭМОЦИОНАЛЬНОЕ НАПРЯЖЕНИЕ ОПЕРАТОРОВ В УСЛОВИЯХ ГРУППОВОЙ ДЕЯТЕЛЬНОСТИ}

\section{В.Г. Цуркан}

Резюме. Установлены с теоретических позиций особенности мобилизации резервов адаптации организма у диспетчеров, управляющих движением поездов, а также взаимосвязи психофизиологических функций при решении проблемы профилактики профессионально обусловленных заболеваний.

Ключевые слова: оператор, напряженность, функциональное состояние.

\section{STATE OF PSYCHOLOGICAL HEALTH ASSESSMENT FOR OPERATORS IN CONDITIONS OF COLLECTIVE ACTIVITY}

\section{V.G. Tsurkan}

Abstract. The peculiarities have been established in the viewpoint of theory of the mobilization of body reserves adaptation in the rail way yard-masters and interrelation of psycho-physiological functions while solving the problem of occupational diseases prevention.

Key words: operator, tension, functional condition.

Donetsk separate subdivision of public institution in the
"Laboratory centre for railway transport of state sanitary
and epidemiological service of Ukraine" (Donetsk)

Рецензент - доц. Н.С. Карвацька

Buk. Med. Herald. - 2014. - Vol. 19, № 1 (73). - P. 200-204

Надійшла до редакції 17.07.2014 року

(C) В.Г. Цуркан, 2014 